\title{
Product development in the automotive industry: crucial success drivers for technological innovations
}

\author{
Daniel Gerhard*, Alexander Brem \\ and Kai-Ingo Voigt
}

Friedrich-Alexander University of Erlangen-Nuremberg

Lange Gasse 20

90403 Nuremberg, Germany

E-mail: gerhard@industriebetriebslehre.de

E-mail: brem@industriebetriebslehre.de

E-mail: voigt@industriebetriebslehre.de

*Corresponding author

\begin{abstract}
Developing new innovative products in the automotive industry means investing huge sums in advance, as one does not know if the product will be successful on the market after launch. Hence, companies are interested in knowing and measuring the critical success drivers within the development steps. The paper discusses the results of a qualitative meta-analysis of 16 empirical studies on New Product Development (NPD) success, which was carried out to gain deeper insight into these success drivers. Furthermore, based on the identification of three main dimensions (development process, resources and strategy), an explorative study in the German automotive industry shows that the findings are confirmed in practice as well. However, the results also indicate that there is still a gap between knowledge about practical relevance of those dimensions and the systematic assessment of these in the process. The study shows interesting approaches of best practices, such as the assessment of product advantage in combination with scenario analysis or the identification of appropriate innovations.
\end{abstract}

Keywords: product development; product innovation; innovation management; automotive industry; R\&D; technology marketing.

Reference to this paper should be made as follows: Gerhard, D., Brem, A. and Voigt, K-I. (2008) 'Product development in the automotive industry: crucial success drivers for technological innovations', Int. J. Technology Marketing, Vol. 3, No. 3, pp.203-222.

Biographical notes: Daniel Gerhard received his Diploma in Engineering and Management from the Friedrich-Alexander University of Erlangen-Nuremberg, Germany in 2006. Since then, he has been working as Senior Research and Teaching Assistant at the University of Erlangen-Nuremberg. His research interests are technology and $R \& D$ management as well as product development.

Alexander Brem received his Diploma in Business Administration from the Friedrich-Alexander University of Erlangen-Nuremberg, Germany in 2004, and earned his PhD there in 2007. From 2004 to 2007, he was Senior Research and Teaching Assistant at the University of Erlangen-Nuremberg, where he now works as Senior Lecturer. Moreover, he is the Founder and partner of VEND consulting GmbH, Nuremberg. His current research interests include idea and innovation management and strategic management in SMEs. 
Professor Dr. Kai-Ingo Voigt is a Full Professor at the Friedrich-Alexander University of Erlangen-Nuremberg, Germany, where he has held the Chair of Industrial Management since 1998. He received his $\mathrm{PhD}$ in 1991 from the University of Hamburg. His current research focuses are strategic management, innovation and technology management, and production and operations management.

\section{Introduction}

The increasing global competition as well as the convergence of product specifications and performances are the main triggers for continuous innovativeness to remain competitive in the long term. This applies especially to high-technology industries, such as the automotive industry, where success strongly relies on continuous innovation. Against the background of extraordinarily high investments within the development of new products and the often contingent chances of success, efficient product development practices are needed (Clark et al., 1987).

Successful high-technology firms in particular are strongly dependent on a high percentage of new products within their portfolios (Griffin and Page, 1996). The development of new products, however, implies high uncertainty and high investments (Brem, 2008). Hence, companies which are developing new products and services have to bear high inherent risks (Cooper and Kleinschmidt, 1987b; Brown and Eisenhardt, 1995). As the New Product Development (NPD) success is closely connected with the NPD process (Poolton and Barclay, 1998), an effective implementation of the 'right' process is fundamental, in which the possible drivers of such processes are illustrated by technology, market and management.

All development projects have in common that the specific process begins with a more or less concrete product idea that meets specific needs or that creates new needs defined by customers and/or manufacturers, and ends with a product that is launched on the market (Osteras et al., 2006). Still, the process of NPD can be seen from different perspectives. The most common one is to see the process as a continuing sequence of developing steps. Due to their gradual character, these process types are called stage models because each stage represents certain development tasks (Saren, 1994).

\section{An overview of the literature}

'Innovation' and 'product development' are terms which are often used in publications, and not only in academic ones (Hauschildt, 2004). In an academic piece of writing, it is necessary to define these terms accurately as there is no generally accepted definition in the literature (Vahs and Burmester, 2005). The discussion is shown from the process perspective, as this corresponds to the focus of the paper. Hauschildt (2004) further distinguishes the content, subjective and normative perspectives, which are not considered here. As Hauschildt argues, the innovation process consists of all steps from idea to realisation, which also include production scale-up and market launch. According to this, the first two stages of idea generation and idea evaluation can be called idea management (Voigt and Brem, 2005). 
The diffusion of the innovation can be included or excluded depending on the focus of a work. From a process perspective, NPD resembles the innovation process. All steps from idea to market launch are also included (Crawford and Di Benedetto, 2006). In this context, the term 'product development' can be seen in two ways: from a narrow perspective as one step of the innovation or new product development process (e.g., Cooper, 1988) or from a wider perspective as all steps from idea to the developed product, excluding the launch and the production scale-up phases (e.g., Siegwart, 1974). This paper sees product development from the second, wider perspective. Hence, the innovation and NPD process overlap with the product development apart from the market launch and production scale-up. The product development ends when the product is fully developed and ready for production and launch into the market.

There are various approaches to describe the development process. Stage models are widely spread and can be further distinguished in department-stage, activity-stage and decision-stage models (Saren, 1994). Cooper (1994) uses the term 'stage-gate models' of the first, second and third generations. The first generation is a department-stage model, as both Saren and Cooper refer to the development process which was used by the National Aeronautics and Space Administration (NASA). The second generation is, like the third generation, a decision-stage model, but also has elements of activity models as the focus lies on cross-functional activities between the decision points. The third-generation model (see Figure 1) is an advancement of the second generation and is based on Cooper's (1994) results in success factor studies. In addition, Saren (1994) further distinguishes between conversion models, response models and network models. Conversion models focus on the transformation of inputs into outputs, whereas response models concentrate on the reaction of an organisation to change. A newer approach is shown by the network models, which are further developed (e.g., Hart and Baker, 1994; Frenken, 2006). Cooper's studies are based on stage models (of the second or third generation). Since most other authors in the field of success factor studies refer to Cooper (e.g., Kotzbauer, 1992), the study overview and categorisation also refers to stage process models (see Figure 1).

Figure 1 Third-generation stage-gate model

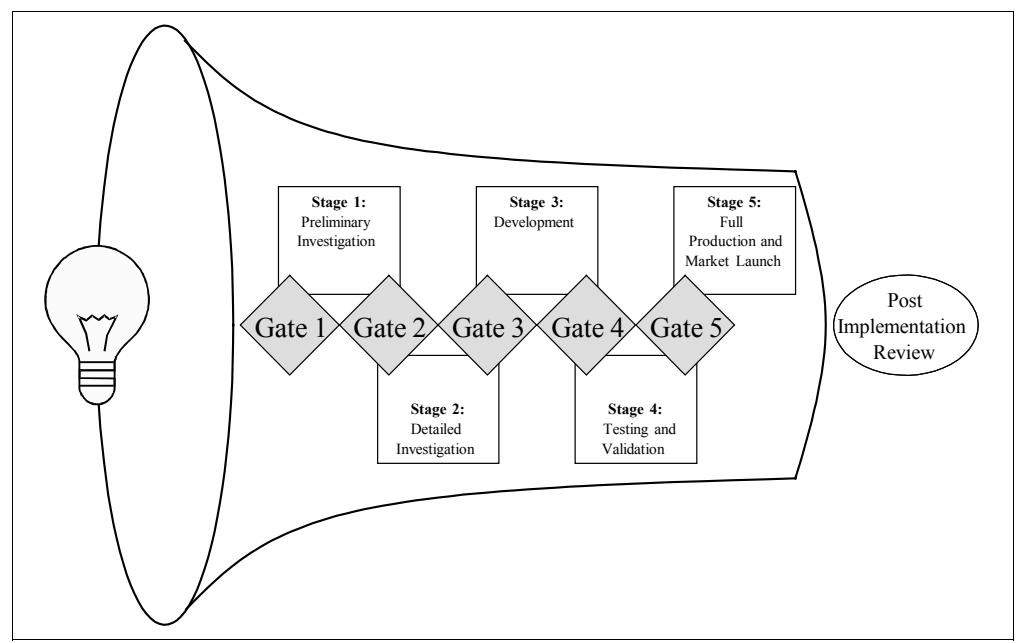

Source: Adapted from Cooper (1996, p.479) 
In the economic literature, a plethora of studies can be found that analyse the success factors of product development. Therein, the studies by Cooper and Kleinschmidt are very well known and are characterised by holistic approaches and the consequent focus on various determinants and factors. Moreover, by looking at the meta-level, several authors have assured a certain stability within the findings (e.g., Montoya-Weiss and Calantone, 1994; Ernst, 2002).

The following overview does not aim to serve as a metastudy itself, but will be the starting point for our study by consolidating the findings into thematic focuses.

Due to the huge amount of existing studies, it was necessary to narrow the scope and to filter the relevant papers for the purpose of this study. Therefore, the following assumptions and constraints were used:

- The considered time frame of the studies analysed is between 1990 and 2006.

- Only studies which research multiple determinants with significant results are included. Therefore, field reports - e.g., from Lester (1998) - are not considered any further.

- In contrast to the production and the market launch phases, it is possible within product development to determine, adjust or change the product features. Therefore, only these phases will be considered.

- The main focus is on the identification of factors influencing the internal conditions, not the external ones, which can be seen as predetermined (Hauschildt, 2004).

- Studies from different countries were analysed. The majority, however, came from the USA. There was no special industry focus defined.

Before a literature and study overview will be given, it is necessary to discuss the term 'success', as a plethora of different definitions can be found. In general, there are two perspectives of success; the first refers to the programme level, the second to the project level (Griffin and Page, 1996). The criteria which are used to investigate success on the project level can be categorised into financial and nonfinancial categories. The nonfinancial criteria can be further subdivided into technological- and customer-based measures (Griffin and Page, 1996). Financial criteria are based on profit, assets, sales, capital and equity (Hart, 1993). On the programme level, success must be seen under the premise of the firm's strategy (Griffin and Page, 1996). Hence, the majority of studies combine financial and nonfinancial aspects into certain dimensions of success which are evaluated by the participants themselves. This procedure is sometimes criticised as being too subjective (Brown and Eisenhardt, 1995).

As a next step, it is important to define the framework for the study. In his later works, Cooper (1998) developed a framework for his international benchmark study, which consists of five dimensions: process, organisation, strategy, culture and commitment. These blocks were drawn out of former studies by Cooper and other researchers in the field of success factor research. The first block, process, basically deals with the different tasks and steps to develop a new product and their quality of execution. Organisational issues refer to the work of cross-functional teams, strong leadership and interfaces between functional departments. The strategy can be seen on the programme and project level. On the programme level, it is important to define the role of new products within the whole strategy of the company. On the project level, the product advantage and the specific product strategy are addressed. The climate for innovation is 
covered by the culture block, which deals with aspects such as risk tolerance and autonomy. The last block refers to the senior management's commitment and consequently to the allocation of necessary resources such as financial, management, marketing and technical resources to development projects.

Our study overview will follow a modified version of this framework. The process is often studied in the economic literature. The most common classification is to distinguish between the process steps from idea to market introduction and to differentiate between technical and marketing activities. Both are studied mainly regarding the quality of execution and the proficiency of these activities (e.g., Cooper and Kleinschmidt, 1986; Parry and Song, 1994; Mishra et al., 1996). Organisational issues are covered, as proposed by Cooper, by researching the role of cross-functional teams and leadership. Strategic issues can be researched on different levels. The creation of a product advantage is an important product-related issue of the strategy (Cooper and Kleinschmidt, 1987a). All other aspects, such as the positioning of the product or conceptual issues, are subsumed under product strategy in general, as further subcategorisation differs from author to author. Cultural aspects are difficult to measure (Schein, 1988). Therefore, these aspects shall not be included in this paper as the field of innovation culture is too broad for a short glance. As Cooper argues, the allocation of resources is one aspect that concerns senior management's commitment. Besides, the commitment deals with the importance of clear messages about the role of new products. In order to deviate from this broad view, the focus of this paper within the commitment block is solely the allocation of resources. Cooper also addresses the aspect of resource allocation separately, introducing his three cornerstones of performance when focusing on the business unit level (Cooper, 1996). Cooper's framework excludes environmental issues. Although these issues cannot be influenced directly, they influence the product success, as Cooper and Kleinschmidt (e.g., 1995c) showed in earlier studies. Therefore, here they are studied in the context of market attractiveness and of the competitive situation, as information about this is important for making the right go-no-go decisions. Hence, our analysis results in five dimensions:

1 development process

2 strategy

3 resources

4 organisation

5 market environment (see Figure 2).

\subsection{Development process}

Diverse process models can be distinguished, although none of these models is generally accepted (Saren, 1994). Within the dimension 'process', the individual development steps and their execution quality can be comprehended. For the purpose of this overview, the widespread model of Cooper (1988) will be used. It consists of a stage-gate process which can be further divided into predevelopment and development activities. The development activities shall include the technical product development and the testing of prototypes; predevelopment activities combine all activities before the technical development itself starts (Cooper, 1988). Since not every author subsumes the same activities under predevelopment, the activities will not be subdivided any further. 
Figure 2 Scope of the literature and study overview

\begin{tabular}{|c|}
\hline Process \\
\hline Process focuses on Market Orientation \\
\hline Quality of Execution, in terms of.. \\
\hline ...Marketing Tasks \\
\hline ...Technical Tasks \\
\hline ..Predevelopment Activities \\
\hline ...Product Development \\
\hline ...Product Testing \\
\hline Strategy \\
\hline Product Advantage \\
\hline Product Strategy \\
\hline Resources \\
\hline Existence of adequate skills/resources, regarding.. \\
\hline ..R\&D \\
\hline ...Marketing \\
\hline Fi.Management \\
\hline ...R\&D \\
\hline ...Marketing \\
\hline ...Management \\
\hline Organisation \\
\hline Leadership \\
\hline Development teams \\
\hline Market Attractiveness \\
\hline Parket Competitiveness \\
\hline
\end{tabular}

A majority of studies emphasise the importance of the execution quality of these steps for NPD success. The predevelopment activities, in particular, are often positively correlated with success within the studies (e.g., Cooper, 1988; Kotzbauer, 1992; Parry and Song, 1994; Cooper and Kleinschmidt, 1995c; Mishra et al., 1996; Cooper, 1998; Cooper and Kleinschmidt, 2000). Cooper and Kleinschmidt stress the importance of predevelopment steps and call them 'up-front homework'. In these phases, important information is gained about customer needs and the competition. This enables an early and clear product definition (Cooper and Kleinschmidt, 1995c). Furthermore, the activities can be divided into marketing and technological activities (Cooper and Kleinschmidt, 1994). On the whole, within the studies, the quality of execution of both kinds of activities is almost of similar importance (Cooper and Kleinschmidt, 1987a; 1994; Calantone et al., 1996; Cooper and Kleinschmidt, 1996; 2000). In contrast, Song et al. (1997) only find a positive correlation for marketing activities. Additionally, the market orientation of the development process also has an impact on product success (e.g., Cooper, 1990; Cooper and Kleinschmidt, 1995b; 1994). Langerak et al. (2004) argue that market orientation has a positive effect on product advantage as well, and hence, on product success. But compared to the quality of execution, it seems to be less important. 


\subsection{Strategy}

From a strategic point of view, following Cooper and Kleinschmidt (1987a), the creation of sustainable product advantage can be seen as a leading edge of the new product strategy, as it has a vital influence on product success (e.g., Zirger and Maidique, 1990; Cooper and Kleinschmidt, 1993b; 1995c; 2000; Song and Parry, 1996; Langerak et al., 2004). Product advantage was constantly identified as a success driver over the considered time period. Therefore, it will be examined separately within this study. These advantages can be the result of one criterion that is seen as a vital advantage, e.g., product quality (Song et al., 1997), or as a combination of various criteria such as higher quality, superior performance and lower customer costs (e.g., Cooper and Kleinschmidt, 1987a; 1993b). The way in which these criteria are combined to a product advantage is differently rated. According to the frequency of mentions within the studies, the most important ones are higher quality (e.g., Cooper and Kleinschmidt, 1987a), uniqueness (e.g., Kotzbauer, 1992), superiority (e.g., Langerak et al., 2004) and product benefits for the costumer (e.g., Cooper and Kleinschmidt, 1987a).

The predominance of specific innovation strategies was studied by Barczak (1995), who could only find a nonsignificant benefit for the fast follower strategy. Cooper and Kleinschmidt (1995c) argue in this context that it is more important to be best, referring to own product superiority, than to be first in the market. The positioning of the new product is important for the product's success (Cooper and Kleinschmidt, 1993b; Yap and Souder, 1994). Strategy has a positive effect not only on the project level, but also on the programme level. Therefore, the business's new product strategy and the role of new products in achieving company goals must be well communicated in order to foster success (Cooper and Kleinschmidt, 1995a; Cooper, 1998). However, further research is needed, as the field of NPD strategy, in particular, has not been adequately researched yet (Ernst, 2002).

\subsection{Resources}

The setting of development projects with the corresponding resources is classified with respect to $\mathrm{R} \& \mathrm{D}$, marketing and management competence. Therein, the resource allocation or commitment and the fit with the project requirements are fundamental (Maidique and Zirger, 1984). A significant difference can be found regarding the extent and compatibility between resources and requirements. Therefore, the compatibility is most important, especially regarding R\&D (e.g., Cooper and Kleinschmidt, 1993b; Mishra et al., 1996; Balbontin et al., 1999) and marketing competence (e.g., Cooper and Kleinschmidt, 1995c; Song and Parry, 1996; Cooper and Kleinschmidt, 2000). The management skills are also relevant to product success (Cooper and Kleinschmidt, 1987c). In general, the more familiar a project is to the company, especially referring to market and marketing familiarity, the better the product's performance will be (Cooper and Kleinschmidt, 1993b).

\subsection{Organisation}

The way R\&D projects are organised can generally be viewed from two perspectives. The first perspective deals with leadership: the existence of a product champion, a person who drives the project even against possible internal resistance (Schon, 1967), has a 
positive effect on the product's success (e.g., Cooper and Kleinschmidt, 1993a; Yap and Souder, 1994; Barczak, 1995), although Yap and Souder (1994) outline that this influence is not significant under high technical uncertainty. In general, the role of the senior management (e.g., Cooper and Kleinschmidt, 1995a; Kotzbauer, 1992; Kristensen et al., 1998; Cooper and Kleinschmidt, 2000) is also relevant to product success. As Cooper (1996) argues, the senior management commitment is an essential prerequisite in order to devote the necessary resources to the R\&D projects. The second perspective deals with the organisation of the development teams. On the team level, the use of cross-functional teams is vital for success. This refers to the project team members from different functions, such as $R \& D$, marketing, manufacturing and engineering (Cooper and Kleinschmidt, 1993b). Cooper and Kleinschmidt (1995a; 1994; 2000) in particular underline the importance of this factor regarding product success.

\subsection{Market environment}

Even though the management cannot directly influence the market environment, it is still important to have a look at this category, because it interacts with the decisions on product strategy (Cooper and Kleinschmidt, 1987a). The attractiveness of a market can be measured, for example, by its size and its growth (Zirger and Maidique, 1990) and has an impact on the success of a new product (e.g., Cooper and Kleinschmidt, 1987c; Kotzbauer, 1992; Yap and Souder, 1994; Mishra et al., 1996). Another factor is the competitive situation. Zirger and Maidique (1990) find a positive correlation between a weak competitive environment and product success. The market attractiveness hence seems more important than the competitive situation, which, however, is rarely studied.

After describing and discussing the introduced five dimensions and the broad spectrum of discussion fields, the findings will be adapted to our research. Based on the analysis of the literature and study research, the dimensions 'process', 'strategy' and 'resources' were selected as the most relevant, according to the frequency with which the individual factors are mentioned within the studies. Hence, the further detailed examination focuses on these three categories (see Figure 3).

Figure 3 Thematic focus for interviews

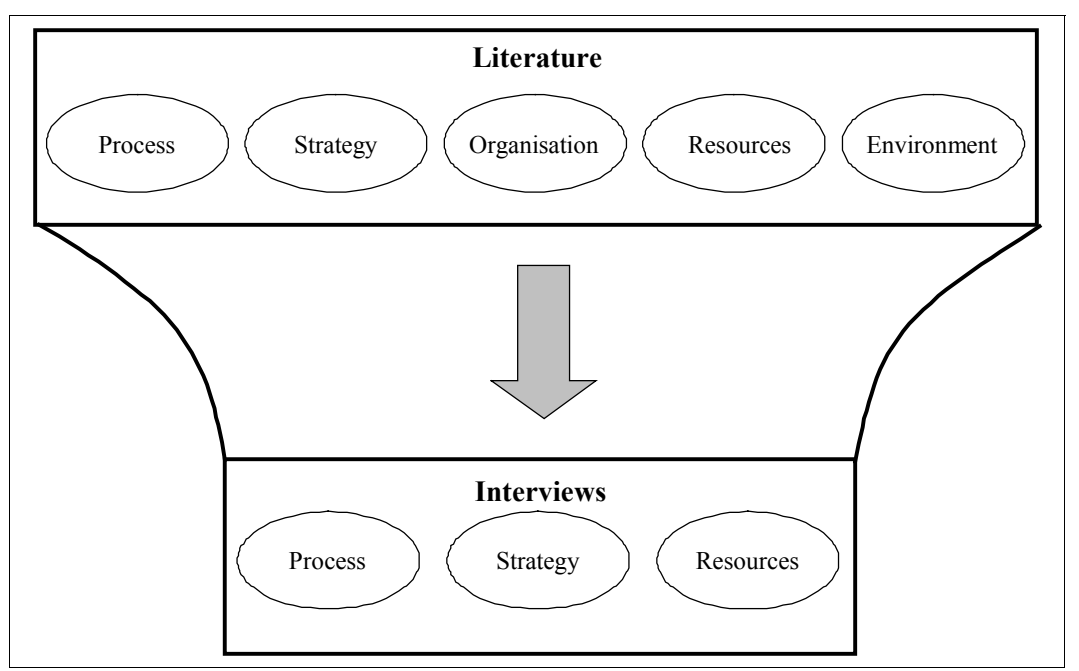




\section{Aim and object of research}

The automotive industry is very important for the German economy (Gerpott, 1999). Car manufacturers have to continuously present new products and innovative solutions in order to sustain their position on the global market. The global market is not homogenous; for example, the US customer has different requirements from the European. Additionally, there are country-specific standards which have to be considered. This leads to more models within a car class and increasing product complexity, and therefore to increasing resulting costs. These circumstances are even more important to German car manufacturers, as they are mainly active in the global premium segments (VDA, 2003; Elsner, 1996). The increasing pressure especially from Japanese manufacturers in the context of alternative drivetrains illustrates the importance of successful product development for German manufacturers. The global trend of environmental issues and, hence, the new focus of the whole industry on ecological mobility enforces this pressure (VDA, 2004; 2007).

However, the top position of German car manufacturers indicates that this industry could serve as a good example for successful development in the past and at present. This also includes the German automotive supplier industry, which is an important driver for innovation (Veloso and Fixson, 2001). Therefore, this high-tech industry was chosen as the research object for this study.

The research contributes to the present study in two ways. Firstly, the conducted interviews give an impression of the specific practical relevance of the identified dimensions for product success and how widely this knowledge is spread in the German automotive industry. The second focus lies in the use of methods to integrate information about these dimensions. Hence, the results enable information about best practices on measuring within those dimensions or show a lack of information concerning this matter. Therefore, this study can also contribute by showing the necessity for further research in this field.

\section{Methodology and data collection}

In order to gain deeper insights into the relevance and characteristics of the various dimensions, a qualitative and explorative study design was chosen. Therefore, primary data were used for this paper. Thus, qualitative expert interviews were conducted to gather the necessary information. In this context, experts are defined as competent persons who are interviewed in their field of experience and for their views concerning the investigated topic (Berekoven et al., 2001). Often the expert himself/herself is the object of the research project (Bogner and Menz, 2002).

In general, three kinds of data collection can be distinguished (Bogner and Menz, 2002). The explorative interview is used to gain insights into new or indistinct topics and to be able to structure a given problem. The systemised interview, on the other hand, aims at the collection of complete data, which also includes the use of an interview guideline. Experts have an advisory function in this context. A theory-generating interview illustrates the third group. Therein, comparable statements of experts are used to formulate a theory by generalising the given statements. 
For this study, the explorative interview was chosen to investigate the impact of strategy, resources and processes on product development: "Interviews are a highly efficient way to gather rich, empirical data, especially when the phenomenon of interest is highly episodic and infrequent" (Eisenhardt and Graebner, 2007, p.28). Therefore, it was necessary to conduct the interview in a relatively open way, by using a guideline. This guideline was designed to fulfil the necessary requirements. In this respect, it outlined the process along general lines (Berekhoven et al., 2001), without determining the course of conversation. Mainly open questions were used. Hence, narrowing the possible answers of the experts was avoided (Böhler, 2004; Witzel, 2000). Twelve qualitative, guided expert interviews were conducted. Regular meetings between managers and researchers were organised to validate our findings and to recognise further issues for analysis.

The interview guideline itself consisted of eight parts. The first two parts covered general sections of information concerning the participants and the company. Afterwards, questions on the R\&D of the specific company were asked. The fourth part consisted of questions about product success. The fifth part focused on the influence of the development process on product success. Within this part, a diagram of the development process was used in addition to the guideline in order to ease the process of answering (see Figure 4). The sixth part focused on the influence of the resources on product success, while afterwards the impact of the product strategy illustrated the seventh part. The guideline was completed by questions relating to the advantage of the developed and launched products.

Figure 4 Development process for interview guideline

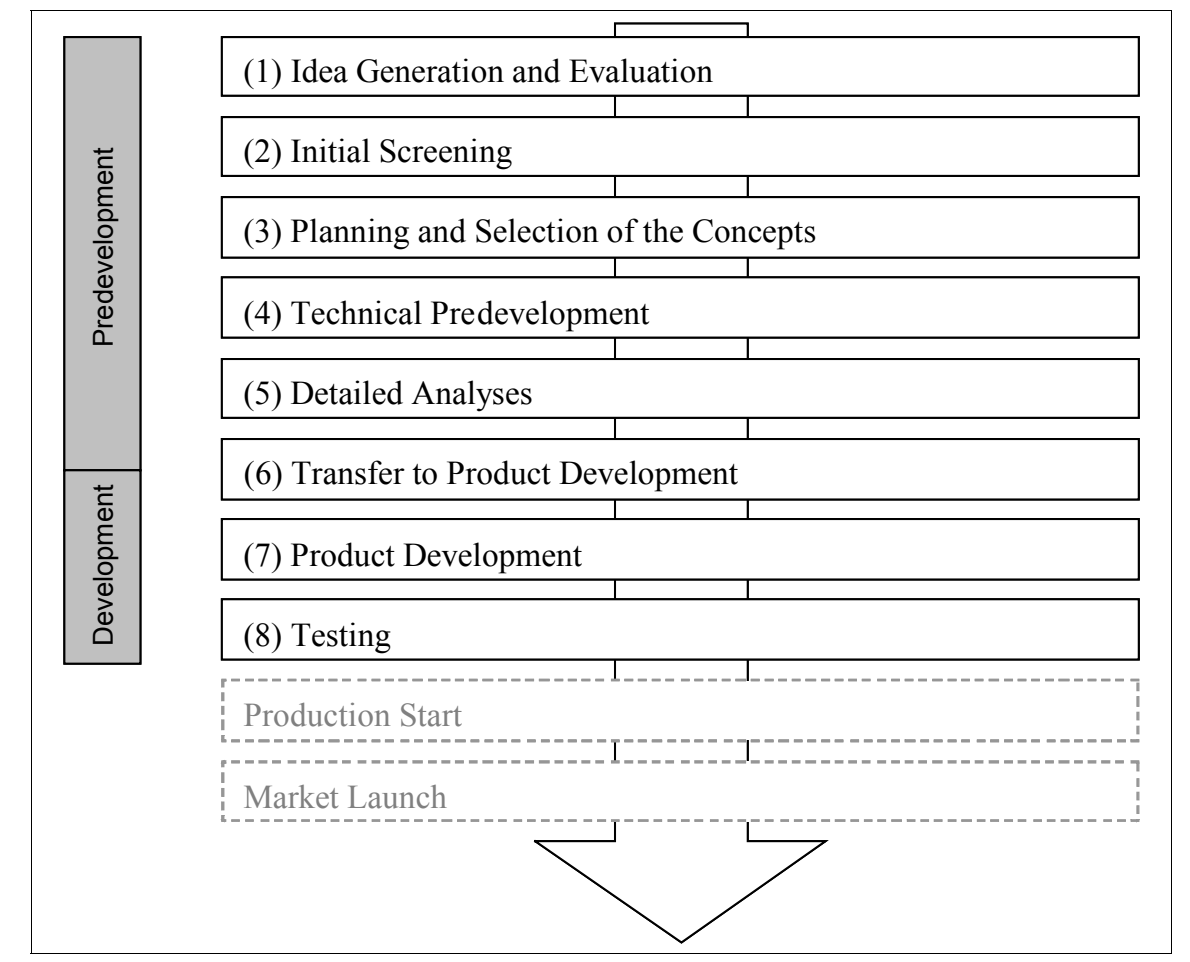

Source: Harland (2002, p.44) 
Before the interviews were conducted, the relevant experts were identified. For this study, the experts had to fulfil the given requirements of working in the automotive (Original Equipment Manufacturer or OEM) or automotive supplier industry and holding at least an upper management position in corporate R\&D. Through diverse databases, appropriate interview partners were identified.

Afterwards, 21 experts were contacted, 12 of whom actually participated in this study. The study was carried out in April and May 2007, while the conversations were mainly conducted via telephone interviews. On average the interviews had a length of 45 mins.

The studied eight suppliers have between 200 and 60000 employees, with sales varying between $€ 40$ and $€ 11,600$ million, and for the four OEMs between $€ 55,000$ and $€ 106,000$ and a turnover from $€ 27$ to $€ 54$ billion. The part the firms invested in $R \& D$, in percentage of their sales, was between $4 \%$ and $13 \%$, whereas the R\&D expenses varied to a greater extent among the suppliers.

\section{$5 \quad$ Results and discussion}

As already mentioned, project success can be seen from a financial and a nonfinancial perspective. Within our sample the majority of the researched companies use sales, return on sales and development costs to measure product success in the financial dimension (see Figure 5). One company also assigns costs which occur during production, (e.g., investment costs for machinery tools or production scale up to product development success measurement), although the interview partner underlined that a clear assignment is difficult in certain cases (e.g., to say exactly which part of those costs are caused by development activities and not by production activities). The results confirm the findings of Griffin and Page (1996), who researched the success measurement of development projects for different strategies. In deviance from their results, the time of reaching the break-even point was not mentioned by the interviewees.

Figure 5 Assessment of success with financial criteria in the researched companies

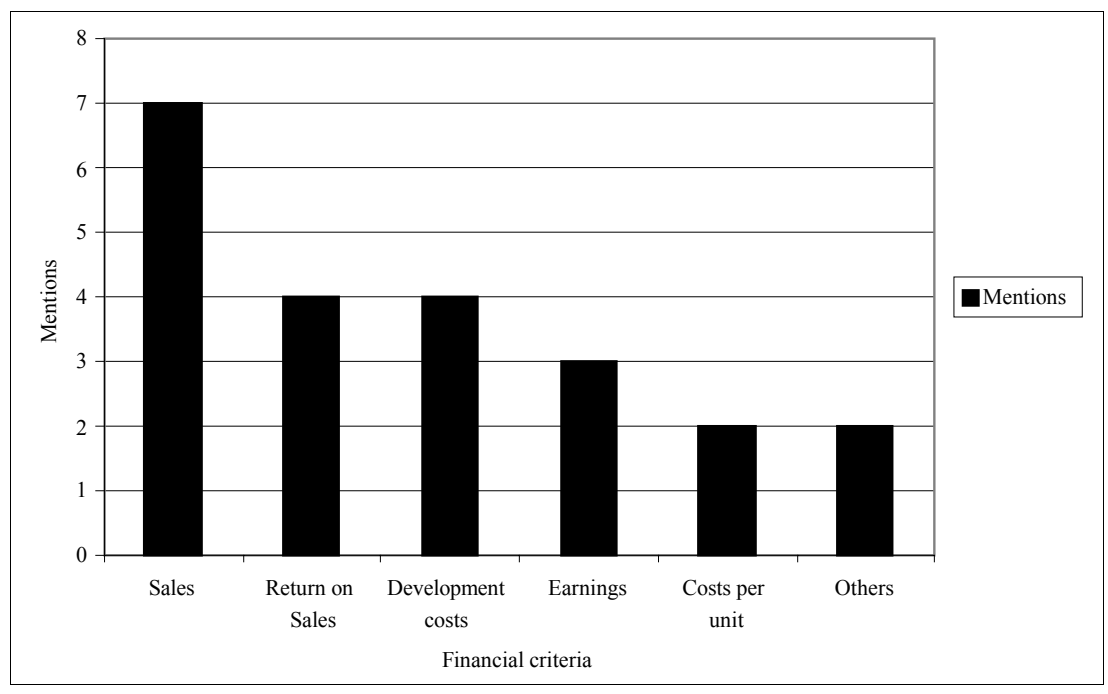


A plethora of nonfinancial criteria were used by the investigated companies. The most common criterion therein is the degree of fulfilment of technical requirements, which are documented in the product specifications. The measurement and assessment of quality is also seen as an important factor. OEMs in particular consider external information in this context, in addition to the internal assessment of product or component quality (see Figure 6). The external information is mainly based on external, objective product tests in automotive journals which conduct vehicle comparison tests. OEMs also carry out similar tests during development with their prototypes to benchmark their products. Although these tests just illustrate a status quo consideration, the criteria and the benchmarking results are then used to derive project goals for NPD. If automotive suppliers assess quality, they mainly rely on component-specific failure rates. In contrast to the usual approach in the economic literature (Griffin and Page, 1996), the customer satisfaction was not assessed in the researched firms. The external information on comparison tests can be seen as the measurement of technological and cost competitiveness, referring to a categorisation by Hart (1993). Quality aspects were not separately mentioned in the literature but were ranked second most important by the interviewees. Therefore, they seem to be especially important in the automotive industry.

Figure 6 Assessment of success with nonfinancial criteria in the researched companies

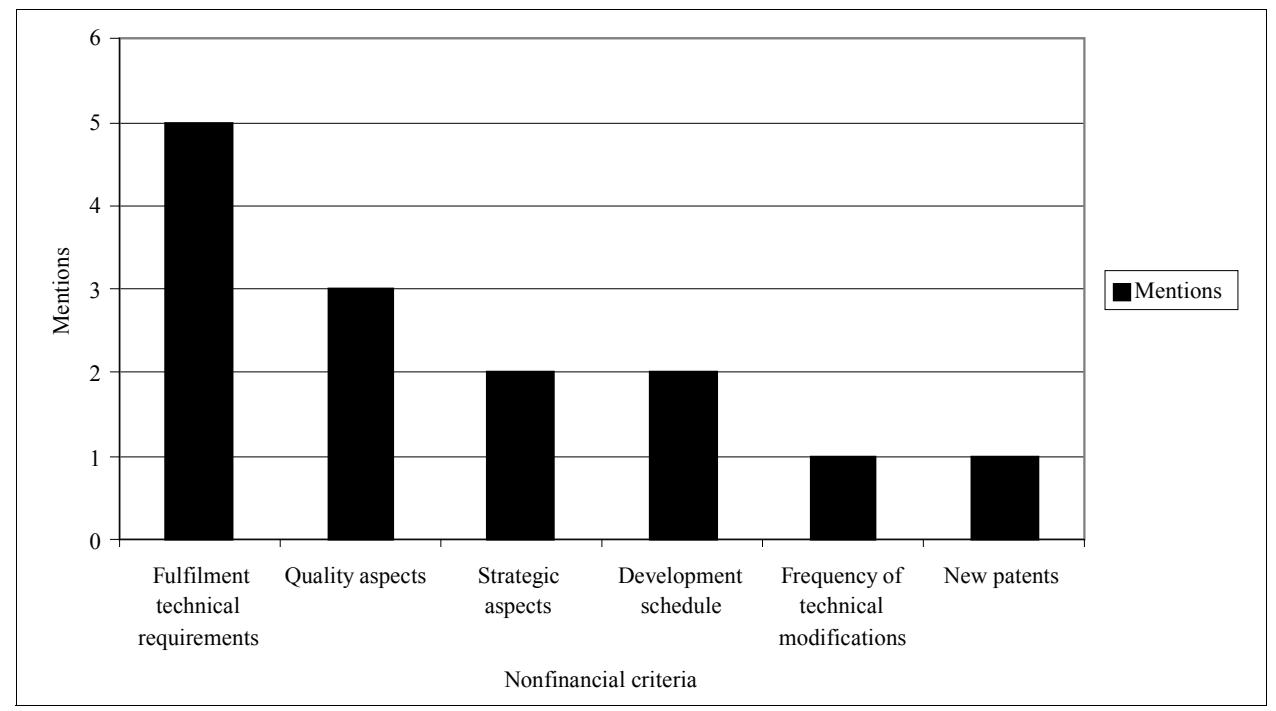

The concrete reviewing of strategic issues was used only by two of the researched companies. In this context, an interesting approach was the use of business plans as controlling instruments for strategic success. The completion of project goals on schedule was surprisingly only rated twice as a criterion for success measurement. However, not being on schedule led to a negative evaluation of some NPD projects. Projects were evaluated mainly as less or not successful if they exceeded the budgeted development costs.

The structure of the given development process was generally confirmed by all interview partners. Some suppliers start their process with an acquisition phase before creating ideas for a new appointment. In almost all firms, an initial screening was 
undertaken before a project entered the concept phase. This screening mostly consisted of market studies, financial analyses and analyses of customer needs. This is followed by the planning and selection of a concept. Not all companies gave pieces of information concerning the precise concept selection. One approach for the selection process was realised by carrying out a benchmark of the generated concepts according to the relevant success criteria, such as customer needs and financial data.

The activities of the initial screening phase and the concept planning phase were rated to be most relevant for product success by 11 participants. Hence, the results of Cooper and Kleinschmidt (e.g., 1986), which show that the predevelopment phase is very important for product success, can be confirmed within our study. An OEM argued that the reason why the concept phase nowadays gets even more attention is that the concept of new cars is a good way to implement product differentiation, as the product quality is on a similarly high level among all direct competitors. The length of the implemented processes differs from company to company. All companies involved in the study acknowledged that the activities which were given by the process in the interview guideline are being undertaken in their companies. However, these activities are integrated in a different way in formal process phases. One participant said that the development process of his company only consists of three large phases; another company has the same activities in a process with nine main steps. Suppliers in particular argue that the process structure is more theoretical because each project has to be adjusted to the needs and requirements of the customer, which means an OEM. This adjustment was realised by defining collective process gates to which the suppliers have to give a status report or deliver certain prototype parts.

The project's progress within the process was measured by review points or quality gates. The degree of product maturity was not measured separately, e.g., between certain review points, by ten firms. An integrated data-based concept to measure the degree of product maturity was only used by one company. This database also allowed the assessment of the different requirements or the definition of no-go-citeria. Another firm plans the implementation of a similar or adequate system but still uses requirement checklists to assess the momentary degree of product maturity. The other companies argued that the degree of maturity was indicated by different prototypes, but also stated that the degree of maturity was not systematically detected in the course of the whole product development process, basically because an integrated approach would be too complex. The one firm with a database-related maturity assessment also admitted that the first implementation of the database for a new product is time intensive. However, the use of the database was seen as a benefit to the development.

A common problem within this process is the change in customer needs, which makes an adjustment of the concept necessary. Such changes disrupt the process and are one of the main reasons for project delays. Nevertheless, the R\&D managers assess these changes as necessary for the product and its later success on the market. Suppliers additionally argue that a change in the concept entails new complex negotiations about development contract details such as development costs and project target dates. Furthermore, the interviews showed that some suppliers think that the demanded development times are too short, even sometimes too short for proper development work with an accordant emphasis on quality issues. 
Table 1 Results within the dimension 'process'

\begin{tabular}{ll}
\hline Dimension: Process \\
\hline Relevance & Measurement \\
\hline Predevelopment activities in particular & Attribute-oriented product maturity measurement \\
were rated as important for later success. & was only implemented in one firm. \\
The concept phase is becoming more and & $\begin{array}{l}\text { Mostly stage-gate processes were implemented, } \\
\text { more important for product differentiation } \\
\text { in the automotive development. }\end{array}$ \\
\hline
\end{tabular}

The sixth part of the questionnaire focused on the role of different resources concerning product success. First of all, the interview partners were asked to rate the importance of R\&D skills, marketing skills, management skills and financial resources on product success by arranging them hierarchically. As Figure 7 shows, R\&D and marketing skills were often ranked as most important. R\&D resources seem to be of particular importance as half of the participants rank them first or second. Marketing skills are also often ranked as most important, although the majority ranks them third or fourth. Hence, it is difficult to make a statement about the relevance of that resource from these results. The economic literature sees R\&D and marketing skills as almost equally important. This cannot be clearly confirmed by our results. Some companies even saw the marketing tasks in the early development stages as inputs to product development, as the marketing unit defines the product requirements which $R \& D$ has to realise. This procedure can be considered critical in connection with a "throw-it-over-the-wall-mentality" (Saad et al., 1991). Most participants ranked the management skills as second most important, independent of which resource they put in first place. The interviewees argued that on the whole, management skills are the key to good project management in general and therefore influence the product's success. Financial resources are less important compared to the other resources. As one participant argued, financial resources are necessary but do not influence product success directly. Therefore, it was only rated twice as the most or second most important factor. R\&D skills represent the bottleneck in most projects. Notably, when a new project starts, there is a lack of adequate R\&D skills in some companies. One explanation was the high uncertainty in young development projects, and therefore some companies hesitate to detach their specialists from projects which are almost completed. Another participant explained that in his company, a lack of $\mathrm{R} \& \mathrm{D}$ resources is compensated for differently depending on the progress of the project. Therefore, at early stages it is important to dispatch employees to the projects, because these are the critical stages. In later phases, when tasks are more standardised, these deficiencies can be more easily compensated for with external resources.

Eleven interview participants agreed that the fit of resources and project needs is more important than the amount of resources. Only one respondent argued that the overall amount of resources is more important as people can become familiar with the new project if they participate in it. Although the fit of resources and needs was rated as more important, only four companies stated that the fit is evaluated systematically. Two of them rely on a database system which contains the skills and experiences of all the employees. Within the remaining two firms, there is no database system, but the managers compare resources and needs in the planning stage. The eight remaining companies have no systematic approach to asses the fit between resources and 
requirements. Therefore, the accordant matching process is within the discretion of the responsible R\&D managers. Although the fit of resources was rated as important, only a minority of the researched firms assess the resource-requirements fit. Most interviewees could not explain why it is not evaluated. Two respondents argued that a systematic fit is too complex and that every manager has his/her own method to match the resources and requirements for his/her employees.

Figure 7 Importance of resources according to ranking

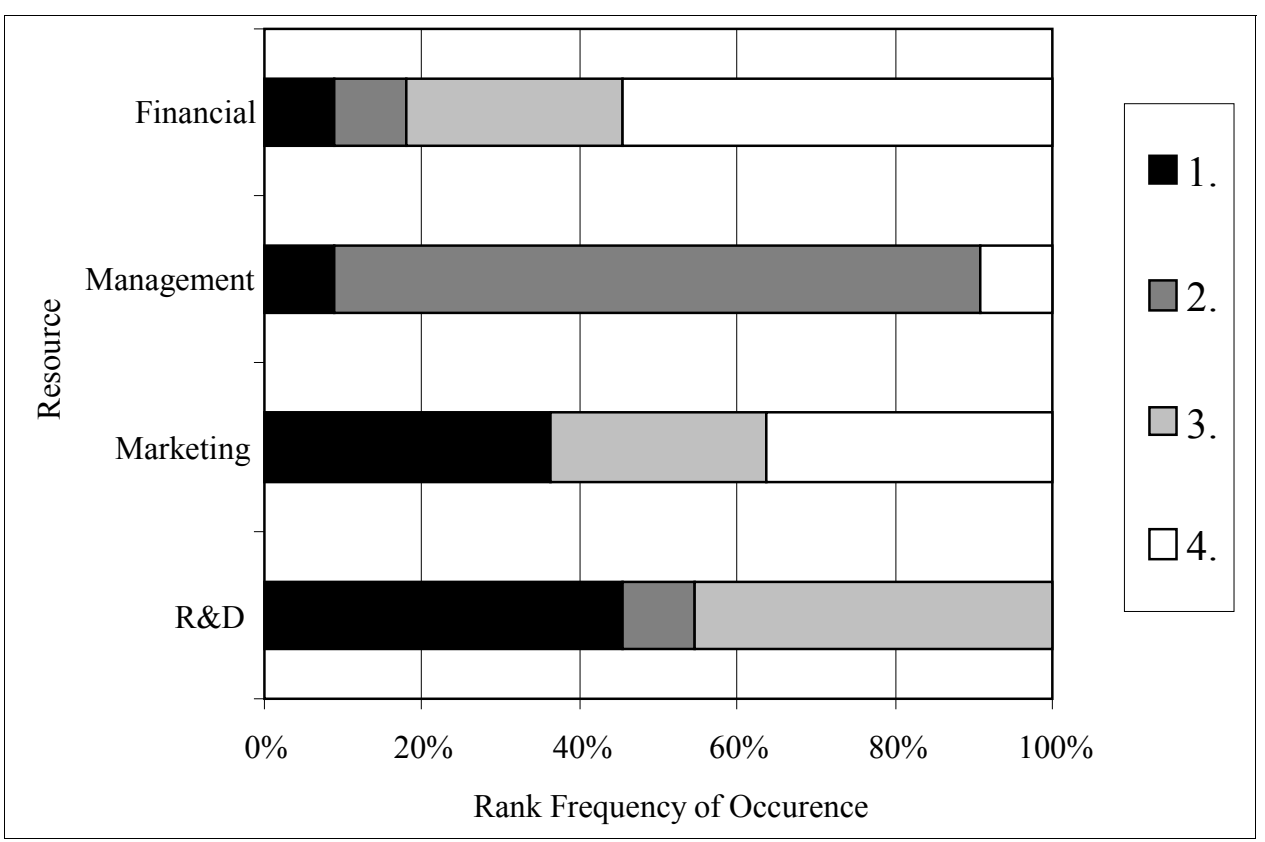

Table 2 Results within the dimension 'resources'

\begin{tabular}{|c|c|}
\hline \multicolumn{2}{|l|}{ Dimension: Resources } \\
\hline Relevance & Measurement \\
\hline $\begin{array}{l}\text { Management and R\&D skills were rated as } \\
\text { most important followed by marketing skills. }\end{array}$ & $\begin{array}{l}\text { Resource allocation is planned at the beginning } \\
\text { of projects. }\end{array}$ \\
\hline $\begin{array}{l}\text { The fit of resources with requirements is more } \\
\text { important than the total amount of resources. }\end{array}$ & $\begin{array}{l}\text { The resource-requirement fit is not evaluated by } \\
\text { the majority of interviewed companies. Only } \\
\text { four firms evaluate the resource-requirement } \\
\text { fit systematically. }\end{array}$ \\
\hline
\end{tabular}

Product strategy formed the seventh part of the questionnaire. All four OEMs could give clear information about their firm's product strategy. The automotive suppliers, on the other hand, sometimes had problems with giving a clear picture of their firms' product strategy. The product strategy is represented during early decisions within the process by assessing how the new product would match the strategy. Another approach, which was introduced in one company, is the identification of and the search for 
'lighthouse' innovations, which are supposed to have the potential to sustain product strategy better than other ideas. Still, in general, the information on product strategy was rather fuzzy.

The last part of the interviews concentrated on the product advantage and how it is measured. Not surprisingly, all companies could name their specific product advantage in comparison to their competitors. Mainly lower costs, higher quality and technical superiority were mentioned. These advantages were measured by benchmarks which are undertaken on a regular basis and especially during development phases with product prototypes. The information of these benchmarks is used to derive goals for future products. One company even accomplishes regular scenario analyses based on the results of present benchmarks to get an overview of the possible future strategies of competitors, and therefore uses this to formulate their aims more precisely. All technical or cost issues are measured and rated according to their importance. All other issues have to be assessed subjectively. As already mentioned, OEMs further obtain external information by analysing the tests of their vehicles in the automotive press. The rating criteria of these tests are also used in the same way in internal benchmarks during product development to gain information on how the product will compete on the market.

Table 3 Results within the dimension 'strategy'

\begin{tabular}{ll}
\hline Dimension: Strategy & \\
\hline Relevance & Measurement \\
\hline OEMs had a clearer view of their product & $\begin{array}{l}\text { At the beginning, new products are evaluated } \\
\text { on how they fit product strategy. } \\
\text { strategy than the suppliers. }\end{array}$ \\
$\begin{array}{l}\text { One firm tries to identify 'lighthouse } \\
\text { specific product advantages in comparison }\end{array}$ & $\begin{array}{l}\text { innovations' which sustain the strategy better } \\
\text { than others. }\end{array}$ \\
& $\begin{array}{l}\text { Product advantage is measured by inherent } \\
\text { to their competitors. }\end{array}$ \\
& attributes in product tests. OEMs also consider \\
& external information from the automotive press. \\
\hline
\end{tabular}

\section{Conclusion}

All companies involved in the study had implemented a formal development process based on defined review points, in which early process phases were seen as critical for product success. Therein, the meaning and importance of the concept phase was emphasised by the participants. This phase was seen as critical within the development process for implementing product differentiation. As one respondent argued, the reason for this are changes in the automotive industry, in which the car concept gets more and more important for differentiation, whereas the technical aspects are becoming more equal among the OEMs. Surprisingly, only one firm mentioned constantly measuring the maturity of the developed product. This interviewee admitted that it means a lot of work to define the relevant attributes in the database, especially at the beginning of the process, but that it also enables a very effective project control. On the whole, the findings of the success factor studies have found their way into the automotive industry, as the participants were aware of the critical predevelopment phases. 
The conclusion on the aspect of resources is more sophisticated. Marketing resources were evaluated to be less important than R\&D skills, which shows a discrepancy with our study overview. Nevertheless, it is not possible to make a clear statement on marketing skills from our results. Management skills in reference to project management were ranked as second most important, which shows the importance of project management skills in the automotive industry. The majority of the participating companies stated that they do not systematically match the fit of resources with project needs, although the fit of resources and requirements was rated as more important than the total amount of resources by the majority. Therefore, a discrepancy between the practical relevance and the implementation of an appropriate assessment of the resource-requirement fit was shown.

The product advantage as part of the strategy was measured in all companies participating in the research. This illustrates a good starting point for defining goals for future products. The information gained by product tests was used for future products even in combination with scenario analysis, which is a complex but interesting approach. On the other hand, the information on product strategy was not detailed enough to allow considerations. Hence, further research particularly in this field is needed to gain deeper insights into how the strategy influences the product's success, especially in the automotive industry.

\section{$7 \quad$ Limitations and further research}

Although the introduced dimensions and their subdimensions are a first attempt to develop specific measures and indicators for future product success, and hence management recommendations for appropriate influential strategies, the findings cannot be generalised. Firstly, the companies in this study all operate in the automotive industry. Hence, the findings could be influenced by industry-specific conditions and characteristics. Further research could include companies from different industries and branches. Moreover, intersectoral comparisons offer an opportunity for further research.

Secondly, the analysed companies belong to different stages in the value creation chain within the automotive industry, as OEMs and suppliers were included. Level-specific conditions could influence the informational value of the findings. Further research could investigate whether OEMs and suppliers have different underlying constraints that significantly influence the product development success.

Additionally, the findings of this study remain in the area of tendency statements, as they could not be proved based on statistical significance. Therefore, quantitative surveys with a broader sample could be conducted.

Furthermore, the sample consists of companies with different sizes (e.g., number of employees, revenues). If a quantitative research design was chosen, future research could try to identify and analyse strategic groups to see whether those groups generally differ regarding the importance of strategy, resources and the process during the product development process. This would be especially interesting for automotive suppliers as their sizes differ more than the sizes of the OEMs.

In the field of the development processes, further research could clarify how the measurement of product maturity influences the product success or what kind of useful information could be gained by this. Regarding the resources, it is necessary 
to find the reasons why the majority of firms do not systematically evaluate the resource-requirement fit and to illustrate the experiences and methods of firms which already use methods to systematically match resources and requirements. The work could draw parallels to other industries and help to identify practices which can be applied to automotive development. As argued above, specific research on product strategy within the automotive industry is necessary to enable detailed managerial implications.

\section{Acknowledgement}

The authors wish to pay tribute to Mr. Christian Willi Scheiner for his unpayable support.

\section{References}

Balbontin, A., Baback, Y., Cooper, R. and Souder, W.E. (1999) 'New product development success factors in American and British firms', Technology Management, Vol. 17, pp.259-280.

Barczak, G. (1995) 'New product strategy, structure, process, and performance in the telecommunications industry', Journal of Product Innovation Management, Vol. 12, pp.224-234.

Berekoven, L., Eckert, W. and Ellenrieder, P. (2001) 'Marktforschung', Methodische Grundlagen und praktische Anwendung, Wiesbaden: Gabler.

Bogner, A. and Menz, W. (2002) 'Das theoriegenerierende Experteninterview: Erkenntnisinteresse, Wissensformen, Interaktion', in A. Bogner, B. Littig and W. Menz (Eds.) Das Experteninterview: Theorie, Methode, Anwendung, Stuttgart.

Böhler, H. (2004) 'Marktforschung', in H. Diller and R. Köhler (Eds.) Edition Marketing, Stuttgart.

Brem, A. (2008) The Boundaries of Innovation and Entrepreneurship - Conceptual Background and Selected Theoretical and Empirical Aspects, Wiesbaden: Gabler.

Brown, S.L. and Eisenhardt, K.M. (1995) 'Product development: past research, present findings, and future directions', Academy of Management Review, Vol. 20, pp.343-378.

Calantone, R.J., Schmidt, J.B. and Song, X.M. (1996) 'Controllable factors of new product success', Marketing Science, Vol. 15, pp.341-358.

Clark, K.B., Chew, W.B. and Fujimoto, T. (1987) 'Product development in the world auto industry', Special Issue On Microeconomics, Brookings Papers on Economic Activity, Vol. 1987, No. 3, pp.729-781.

Cooper, R.G. (1988) 'Predevelopment activities determine new product success', Industrial Marketing Management, Vol. 17, pp.237-247.

Cooper, R.G. (1990) 'New products: what distinguishes the winners?', Research Technology Management, Vol. 33, No. 6, pp.27-31.

Cooper, R.G. (1994) 'Third-generation new product process', Journal of Product Innovation Management, Vol. 11, pp.3-14.

Cooper, R.G. (1996) 'Overhauling the new product process', Industrial Marketing Management, Vol. 25, pp.465-482.

Cooper, R.G. (1998) 'Benchmarking new product performance: results of the best practices study', European Management Journal, Vol. 16, pp.1-17.

Cooper, R.G. and Kleinschmidt, E.J. (1986) 'An investigation into the new product process: steps, deficiencies and impact', Journal of Product Innovation Management, Vol. 3, pp.71-85.

Cooper, R.G. and Kleinschmidt, E.J. (1987a) 'New products: what separates winners from losers', Journal of Product Innovation Management, Vol. 4, pp.169-184.

Cooper, R.G. and Kleinschmidt, E.J. (1987b) 'Success factors in product innovation', Industrial Marketing Management, Vol. 16, pp.215-223. 
Cooper, R.G. and Kleinschmidt, E.J. (1987c) 'What makes a new product a winner: success factors at the project level', $R \& D$ Management, Vol. 17, pp.175-189.

Cooper, R.G. and Kleinschmidt, E.J. (1993a) 'New-product success in the chemical industry', Industrial Marketing Management, Vol. 22, pp.85-99.

Cooper, R.G. and Kleinschmidt, E.J. (1993b) 'Uncovering the keys to new product success', Engineering Management Review, Vol. 11, pp.5-18.

Cooper, R.G. and Kleinschmidt, E.J. (1994) 'Determinants of timeliness in product development', Journal of Product Innovation Management, Vol. 11, pp.381-396.

Cooper, R.G. and Kleinschmidt, E.J. (1995a) 'Benchmarking firms' new product performance \& practices', Engineering Management Review, Vol. 23, pp.112-120.

Cooper, R.G. and Kleinschmidt, E.J. (1995b) 'Benchmarking the firm's critical success factors in new product development', Journal of Product Innovation Management, Vol. 12, pp.374-391.

Cooper, R.G. and Kleinschmidt, E.J. (1995c) 'New product performance: keys to success, profitability \& cycle time reduction', Journal of Marketing Management, Vol. 11, pp.315-337.

Cooper, R.G. and Kleinschmidt, E.J. (1996) 'Winning business in product development: the critical success factors', Research Technology Management, Vol. 39, No. 4, pp.18-30.

Cooper, R.G. and Kleinschmidt, E.J. (2000) 'New product performance: what distinguishes the star products', Australian Journal of Management, Vol. 25, pp.17-46.

Crawford, M. and Di Benedetto, C.A. (2006) New Products Management, New York: McGraw-Hill.

Eisenhardt, K.M. and Graebner, M.E. (2007) 'Theory building from cases: opportunities and challenges', Academy of Management Journal, Vol. 50, No. 1, pp.25-32.

Elsner, U. (1996) 'Kooperationsstrategien internationaler Automobilhersteller unter besonderer Berücksichtigung der horizontalen Kooperation', Gießen: Dissertation University of Gießen.

Ernst, H. (2002) 'Success factors of new product development: a review of the empirical literature', International Journal of Management Reviews, Vol. 4, pp.1-40.

Frenken, K. (2006) 'Technological innovation and complexity theory', Economics of Innovation \& New Technology, Vol. 15, pp.137-155.

Gerpott, T. (1999) Strategisches Technologie- und Innovationsmanagement: Eine konzentrierte Einführung, Stuttgart: Schäffer-Poeschel.

Griffin, A. and Page, A.L. (1996) 'PDMA success measurement project: recommended measures for product development success and failure', Journal of Product Innovation Management, Vol. 13, pp.478-496.

Harland, P.E. (2002) Kooperationsmanagement, Fischbachtal: Harland Media.

Hart, S.J. (1993) 'Dimensions of success in new product development: an exploratory investigation', Journal of Marketing Management, Vol. 9, pp.23-41.

Hart, S.J. and Baker, M.J. (1994) 'The multiple convergent processing model of new product development', International Marketing Review, Vol. 11, pp.77-92.

Hauschildt, J. (2004) Innovationsmanagement, München: Vahlen.

Kotzbauer, N. (1992) 'Erfolgsfaktoren neuer Produkte; Synopsis der empirischen Forschung (Teil II)', GfK: Jahrbuch der Absatz- und Verbrauchsforschung, Berlin: Duncker \& Humblot, pp.108-128.

Kristensen, K., Ostergaard, P. and Juhl, H.J. (1998) 'Success and failure of product development in the Danish food sector', Food Quality and Performance, Vol. 9, pp.333-342.

Langerak, F., Hultink, E.J. and Robben, H.S.J. (2004) 'The impact of market orientation, product advantage, and launch proficiency on new product performance and organizational performance', Journal of Product Innovation Management, Vol. 21, pp.79-94.

Lester, D.H. (1998) 'Critical success factors for new product development', Research Technology Management, Vol. 41, pp.36-44. 
Maidique, M.A. and Zirger, B.J. (1984) 'A study of success and failure in product innovation: the case of the U.S. electronics industry', IEEE Transactions on Engineering Management, Vol. 31, pp.192-203.

Mishra, S., Kim, D. and Lee, D.H. (1996) 'Factors affecting new product success: cross-country comparisons', Journal of Product Innovation Management, Vol. 13, pp.530-550.

Montoya-Weiss, M.M. and Calantone, R.J. (1994) 'Determinants of new product performance: a review and meta-analysis', Journal of Product Innovation Management, Vol. 11, pp.397-417.

Osteras, T., Murthy, D.N.P. and Rausand, M. (2006) 'Product performance and specification in new product development', Journal of Engineering Design, Vol. 17, pp.177-192.

Parry, M.E. and Song, X.M. (1994) 'Identifying new product success in China', Journal of Product Innovation Management, Vol. 11, pp.15-30.

Poolton, J. and Barclay, I. (1998) 'New product development from past research to future applications', Industrial Marketing Management, Vol. 27, pp.197-212.

Saad, K.N., Roussel, P.A. and Tiby, C. (1991) Management der F\&E-Strategie, Wiesbaden: Gabler.

Saren, M. (1994) 'Reframing the process of new product development: from "stages" models to a "blocks" framework', Journal of Marketing Management, Vol. 10, pp.633-643.

Schein, E.H. (1988) 'Organizational culture', Working Paper No. 2088-88, Sloan School of Management, MIT, December.

Schon, D.A. (1967) Technology And Change, New York: Delacorte.

Siegwart, H. (1974) Produktentwicklung in der industriellen Unternehmung, Bern: Haupt.

Song, X.M. and Parry, M.E. (1996) 'What separates Japanese new product winners from losers', Journal of Product Innovation Management, Vol. 13, pp.422-439.

Song, X.M., Souder, W.E. and Dyer, B. (1997) 'A casual model of the impact of skills, synergy, and design sensitivity on new product performance', Journal of Product Innovation Management, Vol. 14, pp.88-101.

Vahs, D. and Burmester, R. (2005) Innovationsmanagement; Von der Produktidee zur erfolgreichen Vermarktung, Stuttgart: Schäffer-Poeschel.

Veloso, F. and Fixson, S. (2001) 'Make-buy decisions in the auto industry - new perspectives on the role of the supplier as an innovator', Technological Forecasting and Social Change, Vol. 67, pp.239-257.

Verband der Automobilindustrie (VDA) (2003) HAWK 2015 - Herausforderung Automobile Wertschöpfungskette, Frankfurt am Main: VDA.

Verband der Automobilindustrie (VDA) (2004) Annual Report 2004, Frankfurt am Main: VDA.

Verband der Automobilindustrie (VDA) (2007) Annual Report 2007, Frankfurt am Main: VDA.

Voigt, K-I. and Brem, A. (2005) 'Integriertes Ideenmanagement als strategischer Erfolgsfaktor junger Technologieunternehmen', in E. Schwarz and R. Harms (Eds.) Integriertes Ideenmanagement - Betriebliche und überbetriebliche Aspekte unter besonderer Berücksichtigung kleiner und mittlerer Unternehmen, Wiesbaden: Gabler, pp.175-200.

Witzel, A. (2000) 'Das problemzentrierte Interview', Forum Qualitative Social Research, Vol. 1, No. 1, www.qualitative-research.net/fqs-texte/1-00/1-00witzel-d.htm (10 February 2007).

Yap, C.M. and Souder, W.E. (1994) 'Factors influencing new product success and failure in small entrepreneurial high-technology electronics firms', Journal of Product Innovation Management, Vol. 11, pp.418-432.

Zirger, B.J. and Maidique, M.A. (1990) 'A model of new product development: an empirical test', Management Science, Vol. 36, pp.867-883. 